Article

\title{
Participation of Children and Parents in the Swiss Child Protection System in the Past and Present: An Interdisciplinary Perspective
}

\author{
Aline Schoch ${ }^{1, *}$, Gaëlle Aeby ${ }^{2, * \mathbb{C}}$, Brigitte Müller ${ }^{1}$, Michelle Cottier ${ }^{2}$, Loretta Seglias ${ }^{3}$, \\ Kay Biesel ${ }^{1}$, Gaëlle Sauthier ${ }^{4}$ and Stefan Schnurr ${ }^{1}$ (D) \\ 1 Institute for Studies in Children and Youth Services, School of Social Work, University of Applied Sciences \\ Northwestern Switzerland FHNW, 4132 Muttenz, Switzerland; brigitte.mueller@fhnw.ch (B.M.); \\ kay.biesel@fhnw.ch (K.B.); stefan.schnurr@fhnw.ch (S.S.) \\ 2 Centre for Evaluation and Legislative Studies, Faculty of Law, University of Geneva, 1211 Geneva, \\ Switzerland; michelle.cottier@unige.ch \\ 3 Independent researcher, 8820 Wädenswil, Switzerland; 1.seglias@unitone.ch \\ 4 Centre for Children's Rights Studies, University of Geneva, 1950 Sion, Switzerland; gaelle.sauthier@unige.ch \\ * Correspondence: aline.schoch@fhnw.ch (A.S.); Gaelle.Aeby@unige.ch (G.A.)
}

Received: 6 July 2020; Accepted: 12 August 2020; Published: 18 August 2020

check for updates

\begin{abstract}
As in other European countries, the Swiss child protection system has gone through substantial changes in the course of the 20th century up to today. Increasingly, the needs as well as the participation of children and parents affected by child protection interventions have become a central concern. In Switzerland, critical debates around care-related detention of children and adults until 1981 have led to the launch of the National Research Program 'Welfare and Coercion-Past, Present and Future' (NRP 76), with the aim of understanding past and current welfare practices. This paper is based on our research project, which is part of this national program. We first discuss three overarching concepts - integrity, autonomy and participation-at the heart of a theoretical framework in order to understand the position of parents and children in child protection proceedings. Secondly, we critically analyze the historical and legal development of the child protection system in Switzerland and its effects on children and parents from 1912 until today. Thirdly, we give an insight into the current Swiss child protection system, with an investigation of hearings of parents and children conducted by the Child and Adult Protection Authorities (CAPA) based on participant observations. In particular, we show the importance of information exchanges and of signs of mutual recognition. Finally, in light of our findings, we discuss the interplay between socio-historical and legal developments in child protection and their consequences for the integrity, autonomy and participation of the people involved.
\end{abstract}

Keywords: child protection; child protection system; participation; integrity; autonomy; historical analysis; legal analysis; participant observation; human rights; children's rights; Switzerland

\section{Introduction}

Since the 1970s, the legal status of children and the question of the best interest of the child have been given greater relevance in Swiss child protection. This has led to several legislative reforms that aimed to emphasize the personal fundamental rights and opportunities for children and parents and facilitated their participation in child protection proceedings. On one hand, these legislative reforms were initiated as a response to the European Convention on Human Rights, which Switzerland ratified in 1974. They also responded to problematic welfare policies and practices in the past, in which persons concerned were not informed, heard or given the opportunity to participate systematically 
in legal decisions and were placed against their will. On the other hand, the reforms were fueled by changing social awareness of the rights and needs of children as well as the growing importance of the UN Convention on the Rights of the Child, which came into force in 1989 and was ratified by Switzerland in 1997. Nevertheless, currently, little is known about the effects of these reforms, how they strengthened the autonomy of children, parents and families and to what extent they promote their integrity and their participation in child protection procedures. Empirical knowledge is lacking regarding the impact of the modified provisions on care-related detention in 1981, which set an end to placements ordered without granting due process of law (so called "administrative detention"). Furthermore, little empirical knowledge is available on the new Child and Adult Protection Authorities (CAPA), which have been in operation since 2013 and have replaced the former layperson-based Guardianship Authorities (Müller et al. 2020).

In view of this fact, in 2017, the Swiss National Science Foundation (SNSF) was commissioned to deepen scientific knowledge of compulsory social measures and placements (coercive welfare measures) in different contexts in Switzerland, following the recognition of harm caused up until the 1980s by the disregard of the fundamental rights of the persons concerned. In order to do so, the National Research Program "Welfare and Coercion-Past, Present and Future" (NRP 76) was launched. The aim of the NRP 76 is to analyze the mechanisms, modes and features of Swiss welfare policy and practice in the past and present. The program has the objective of identifying causes of welfare practices that damaged or restored the integrity of persons concerned. Furthermore, it is a designated goal to explore the effects of welfare practices on persons affected. A total number of 27 research projects have been funded by the SNSF, one of which is our research project, "Intapart: Integrity, Autonomy and Participation: How do children and parents experience child protection?"1 (Swiss National Science Foundation (SNSF) 2020).

"Intapart" addresses the objectives of the NRP 76 by exploring the perceptions of persons subject to compulsory social measures in the past and the present. It researches the subjective experiences of individuals within the child protection system regarding their integrity. The interdisciplinary research design aims to investigate the question of how children and parents understand, experience and respond to what happens to them during child protection proceedings. It includes a historical and legal analysis as well as an empirical study. The historical analysis highlights how children and parents experienced encounters with the child protection system between 1940 and 2012. The legal analysis researches how children's and parents' procedural rights have developed from 1912 to 2012, with a focus on the right to be heard in child protection proceedings. It also tackles the question of how the existing law addresses perceived violations of the integrity, autonomy and participation rights of children and parents. The research questions of the empirical study focus on how children and parents perceive and react to the interventions of CAPA in the current child protection system. It explores what actions the authorities take to protect children from abuse and neglect and to strengthen the rights, legal position and participation of children and parents in child protection proceedings.

In this paper, we start with a theoretical discussion of the overarching concepts of integrity, autonomy and participation and show how closely these concepts are related to one another. We then analyze how the Swiss child protection system has developed from the implementation of the new civil code of 1912 until today. In this context, we focus on the ways in which the rights and needs of children and parents have been considered and describe dramatic state interventions associated with them. We then give an insight into the CAPA's current practice by sharing initial findings of participant observation of interactions with children and parents. Finally, we debate how the child protection system and its stakeholders could ensure that children and parents receive sustainable help, respecting their integrity, autonomy and participation in child protection proceedings.

1 For more details about the project, see: http://www.nfp76.ch/en/projects/interventions-and-pathways-in-life/project-cottier. 


\section{Theoretical Reflections on the Nexus of Integrity, Autonomy and Participation}

Children and parents are at the center of child protection and should thus be considered as active social actors with agency, embedded in complex power relations and as part of dynamic family configurations. Agency describes the capacity to act autonomously and intentionally within a certain social structure and has to be understood as a varying restricting or enabling context (cf. Duncan 2019; Raithelhuber and Schröer 2018, p. 50; for more general critical discussions on the agency of children, see Esser et al. 2016). Social scientists have long overlooked children as active and independent social actors and have considered them rather as objects in need of protection (Bühler-Niederberger 2010; Wolff et al. 2016). In order not to reproduce this blind spot, we suggest considering children as active social actors in line with the "sociology of childhood" (Alanen 1988; Ambert 1986; Corsaro 1997; Qvortrup 1987). Nevertheless, a child-centered perspective also holds the potential of losing sight of the social embeddedness of the child and the existing power relations within and outside the family system. Children in particular are in a structurally weaker position in relation to adults (parents and professionals)—as are parents in relation to child protection professionals (Duncan 2019; Graham and Fitzgerald 2010). Hence, children as well as parents may feel powerless in child protection proceedings, that they are not being heard or listened to or that they are not being recognized (Biesel 2016; Cossar et al. 2016; Dillon 2018; Dillon et al. 2016; Duerr Berrick 2018; Duncan 2019; Husby et al. 2018; Tisdall 2016; Wolff et al. 2016). In order to understand the child protection system and how cases of child abuse and neglect are dealt with, it is therefore necessary to think of integrity, autonomy and participation together as a nexus and a focal point.

\subsection{Integrity}

Within this context, integrity can be defined as a state of soundness and functionality of physical and mental health as well as the opportunity and capability to achieve self-set goals. Autonomy is needed in order to have the capacity to do so (Becker-Lenz and Müller-Hermann 2013, p. 212). Axel Honneth's theory of recognition (Honneth 1995) can be an inspiring approach to define and establish integrity in social interactions.

The theory of recognition refers to three axes of mutual recognition: (1) love linked to self-confidence, (2) rights in the legal sphere linked to self-respect and (3) solidarity linked to self-esteem. The experience of love in close relationships, such as among family members or friends, creates self-confidence. Violence would be at the opposite end and shows disrespect for recognition. Recognition in the legal sphere can be realized in the form of having rights and in the equal treatment of all individuals, which promotes self-respect. The opposite would be exclusion from certain rights. Recognition in the form of solidarity and esteem means being respectful of other people's opinions, attitudes, skills and roles or status and leads to self-esteem. The opposite of this is experiencing shame, the loss of honor or denigration. The experience of disrespect on one axis or multiple axes of recognition can lead to social resistance, conflict and the struggle for recognition of disrespected individuals. By struggling for recognition, an individual tries to re-establish lost dignity. When children are asked about what they consider important about participation, they refer quite directly to these axes of recognition (Graham and Fitzgerald 2010).

Disrespecting social recognition in Honneth's understanding can be seen as the violation of a person's integrity, since experiencing curtailed integrity, e.g., not being listened to, can lead to self-set goals neither being defined nor achieved. Whenever children or parents experience violence in the child protection system, if their legal rights are not respected or if they feel ashamed, they might perceive this as a violation of their integrity. A lack of mutual recognition leads to being held back from achieving (or even formulating) self-set goals, i.e., to preserve integrity. If children or parents resist child protection interventions, it might be that they are trying to restore their recognition by opposing them. It is thus crucial to build up a respectful and trustful relationship between child protection professionals and all family members in order to prevent negative experiences (Husby et al. 2018; Duerr Berrick 2018, p. 38; Husby et al. 2019; Cossar et al. 2016, p. 106f.). 


\subsection{Autonomy}

Autonomy is strongly connected to the conceptualization of integrity defined above and closely related to participation. The concept of autonomy is often associated with that of independence, but it has a broader scope as it also encompasses subjective dimensions (De Singly 2000). Autonomy can be defined as "as an acquired set of capacities to lead one's own life", including "the capacity to develop and pursue one's own conception of a worthwhile life" (Anderson and Honneth 2005, pp. 127, 130) or, in other words, freedom of choice (Join-Lambert Milova 2006). Autonomy can further be understood as the opportunity to live a life in which "reasonable" decisions can be made, and actions can be taken according to these decisions (Becker-Lenz and Müller-Hermann 2013). Duncan (2019, p. 129) suggests questioning critically the notion that families involved in child protection have sufficient agency to make such decisions. She argues that developed agency can be assessed if a decision is based on rational and logical reasons as well as if there is an understanding of the consequences of a certain decision by the persons concerned.

According to Anderson and Honneth, individuals' autonomy is restricted if social relationships of respect, care and esteem are damaged. Being able to re-establish or maintain relationships of mutual recognition is hence a condition for leading an autonomous life (Anderson and Honneth 2005, pp. 127, 131-32). Families involved with the child protection system are often in challenging situations and their autonomy is strained in two ways, as their scope of decision and their scope of action to lead a self-determined life are limited, on one hand, with regard to their personal life, which is often a "highly constrained context", and on the other hand, by state interventions in the form of child protection measures (Tisdall 2016, p. 5). Under such circumstances of potentially damaged (relationships of) recognition-for instance, in the context of social isolation-it can be difficult to take action and make "reasonable" decisions or to express agency (ibid.; Anderson and Honneth 2005). However, according to Beate Rössler (2017), it is possible to live an autonomous and self-determined life under challenging social or biographical conditions-for instance, when facing economic deprivation. Autonomy does not exclude experiencing ambivalent conflicts, emotions and decisions, since wishes and the conditions of their realization are often incompatible. Autonomy should therefore be understood as the reasonable management of such ambivalence (ibid., pp. 393, 395). The crucial condition, however, is that an autonomous person can develop, decide for and stand behind their own undertakings by striving for a self-determined and worthwhile life (Rössler 2017, pp. 394-96). The "social context" in which autonomy can be built must thus-from a perspective of justice-be protected or restored for deprived individuals or groups (Anderson and Honneth 2005, p. 137).

\subsection{Participation}

At the core of theorizing child protection and thinking of integrity, autonomy and participation as a nexus is the capacity to make decisions. Indeed, participation has been recognized as a key concept in child protection (Lansdown 2010; Svevo-Cianci et al. 2011). Developing one's own opinion, achieving self-determined goals (integrity), making self-determined choices and pursuing one's own undertakings (autonomy) require knowledge.

Regarding participation, it is fundamental for children and parents to receive sufficient information on the child protection proceedings and on the child protection system itself, in order to understand and make sense of their situation. Information is a prerequisite to having the capacity to develop, advocate and reflect on a self-determined life and to making "reasonable" decisions (cf. for example, Duncan 2019, p. 135, referring to Giddens' structuration theory). Information is hence central to the concept of autonomy and integrity, as well as to participation (for the relevance of information to participation, see Bouma et al. 2018). Receiving information and understanding the child protection proceedings is also part of the procedural "right to be heard", laid down in the Swiss Federal Constitution (Art. 29 FC). It includes the right to be informed of decisions, to express oneself, to comment on the issues concerning the case and to participate in the process of decision-making. The overarching goal of the "right to be heard" is "effective participation" (Steinmann 2014, p. 661, Eng. translation by the 
authors). In their model of participation, Bouma et al. (2018) include three dimensions: informing, hearing, involving.

Duncan (2019, pp. 141-48) also emphasizes information and a trustful relationship between children and child protection professionals as key factors with regard to children's participation in child protection and has developed an interesting typology of participation, ranging from active participation (congenial participation) to skeptical participation, up to withdrawing (disaffected participation). Specific institutional patterns of information, communication and power structures within organizations are thus a prerequisite to realizing congenial or full participation (Hillmann 1994, pp. 654-55). Dumbrill's study (Dumbrill 2006, pp. 30-33) showed that, when parents perceived child protection professionals as using power "over" them as a form of control, they were more likely to either openly oppose them or to simulate co-operation. When parents felt that power was used "with" them, they tended to collaborate. It is therefore a fundamental need with regard to participation that child protection professionals share power and information with children and parents (Duerr Berrick 2018, p. 38; Husby et al. 2018, p. 444). Holding back information from children and parents can be understood as restricting their power because they are being held in inferior positions compared to the professionals and are hindered in reaching their goals and participating fully (Duerr Berrick 2018, p. 38). To establish a relationship of trust and respect, a certain amount of support as well as clear information and communication is crucial to enable children and parents to participate in decision-making processes (Graham and Fitzgerald 2010; Husby et al. 2018).

In summary, we propose to conceptualize full participation by integrating aspects of the above-mentioned nexus of integrity, autonomy and participation. Participation thus includes aspects of integrity such as receiving recognition by experiencing a trustful and respectful relationship between family members and child protection professionals and by having one's rights and opinions respected as a basis for achieving self-set goals. The precondition for this is the soundness of physical and mental integrity and the opportunity to live autonomously, i.e., to have the capacity to develop and pursue one's own conception of a worthwhile life. To achieve this, families in the child protection system need to have sufficient information to understand the child protection proceedings, implying and understanding of child protection professionals' concerns about problematic parenting practices (Healy and Darlington 2009, pp. 427-28). Information is also crucial in order to anticipate the potential consequences of decisions and hence to get involved, i.e., to fully participate. By these means of full participation, children and parents are given the structural conditions to regain or enhance their agency in a context in which their autonomy is restricted by often highly-constrained social (family) situations and by state intrusion in the form of child protection measures.

\section{The Evolution of the Legal and Institutional Framework of Swiss Child Protection in the 20th Century}

The legal and institutional framework is a crucial factor for the opportunity to substantiate the integrity, autonomy and participation of parents and children in any child protection system. In Switzerland, this framework evolved greatly throughout the 20th century. A structural characteristic that changed only marginally over that time was the high degree of federalism and the principle of subsidiarity. Switzerland is a confederation of 26 cantons, which are rather small units $(16,000$ to 1.5 million inhabitants) but have considerably more autonomy and competencies against the federal level than constituent states in other federal systems usually do. Instead of a homogenized system consisting of uniform institutions, in many aspects, child protection in Switzerland resembles a patchwork of 26 regimes, which can be understood as the result of interactions between federal legislation, cantonal legislation (the reach and regulations of which also varies) and cantonal as well as local patterns of institutionalization and implementation (Schnurr 2017). In order to understand the current state of the Swiss child protection system and its most recent reform in 2013, it is necessary to study its development over time, taking a legal-historical approach. We start with the first nationwide set of regulations that went beyond cantonal legislation on the poor (poverty laws), the federal Swiss 
Civil Code (SCC) of 1912. We analyze the most important changes in the legal and institutional framework throughout the 20th century. While we paint the evolution in broad strokes, our project aims to produce an even more detailed analysis of the experiences of dis-/respect of integrity, autonomy and participation rights of parents and children affected by an intervention of the former Guardianship Authorities between 1978 and 2012 (historical analysis) as well as of the opportunities the law provided between 1912 and 2012 to address perceived violations of these rights (legal analysis).

\subsection{Systematic Disregard for Integrity, Autonomy and Participation in the First Half of the 20th Century}

While private law, including family law, was the responsibility of the cantons in the 19th century, the first federal Swiss Civil Code (SCC) of 1912 codified parental duties at a federal level for the first time and thus acknowledged the state's responsibility for children. The Guardianship Authorities were henceforth legitimated to remove a child from his or her parents if they did not meet their obligations to care for him or her (Häsler 2008). As the focus changed from substantiated neglect and the misery of children to a broader notion of risk and prevention of endangerment, the new law entitled authorities to also remove children on the grounds of suspected or probable neglect (Seglias 2013). This approach to placements was reflected in the "child protection articles" (Art. 283-285 SCC). They introduced the possibility of placing children not only if their families depended on welfare benefits (under poverty laws) but also on the basis of the mere assumption that a family was unable to care for a child, e.g., if the family was seen as "work-shy" or "slovenly" or if the "moral neglect" of a child was claimed (Ramsauer 2000; Leuenberger and Seglias 2015, pp. 232-49). The cantons did not only have the competence to implement these measures under federal law but, until 1981, additionally retained the authority to legislate on the internment of persons, based on the public interest. Thus, cantonal laws aimed to protect the public interest and public order (namely the management of poverty and attendant symptoms), whereas the federal civil law, the SCC, pursued the protection of minors and vulnerable adults. The preventive rationale of this combined federal and cantonal approach to the regulation of childhood created a very broad scope of action for the decision-making authorities and facilitated arbitrariness in sanctioning lifestyles and behaviors judged as deviant (ibid.; Furrer et al. 2014).

The SCC delegated to the authority the responsibility to define the structures and proceedings of the child and adult protection field to the cantons. This concerned the organization of the Guardianship Authorities and the application of the law. Parallel structures were established for the above-mentioned restrictions to a person's freedom and civil rights for reasons such as public order, prevention of poverty, public health, "social prevention", etc. under cantonal public law (Independent Expert Commission (IEC) on Administrative (2019)). The system was predominantly lay-based: the Guardianship Authorities were subdivisions of the elected bodies of municipalities and therefore lay bodies (in most German-speaking cantons) or magistrates (justice of the peace) in the French-speaking part of Switzerland, who had considerable discretion to handle child protection cases (Schnyder et al. 1995, pp. 26-28; Affolter 2013, p. 11). In addition, under cantonal "detention laws", the cantonal welfare authorities were entitled to separate families and place persons, including adolescents, in workhouses for re-education, mental institutions, homes for "fallen women" or even prisons, without court proceedings or court rulings (ibid.). The resulting practice of "administrative detention" led to an estimated tens of thousands of individuals becoming subject to coercive placements over the course of the 20th century up to 1981 (Guggisberg and Molin 2019) ${ }^{2}$. Moreover, the federalist division

2 However, many authors (e.g., Leuenberger and Seglias 2015; Guggisberg and Molin 2019; Schnurr 2017) problematize the general lack of reliable statistics on family or institutional placements, since Switzerland did not and still does not collect them systematically. The Independent Expert Commission (IEC) on Administrative Detention estimates that 40,000 to 60,000 individuals were subject to administrative detention between 1930 and 1980 (Guggisberg and Molin 2019). Leuenberger and Seglias (2015) estimate that 6-10\% of children in the second half of the 20th century (or hundreds of thousands of children in the 19th and 20th centuries) were affected by such forms of family placements ("indentured child laborers"). 
of public tasks implied that regulations and norms for child removal differed considerably between cantons and regions.

With regard to the placement of children, the cantonal introductory acts concerning the application of the SCC were intended to regulate the supervision and inspection of the placements, but, in fact, it took several more decades to put this in place (Leuenberger et al. 2011; Seglias 2013, p. 60). Altogether, this constituted a system of child protection characterized by a multitude of federal and cantonal regulations and proceedings with only marginal mechanisms of control and considerable discretion for stakeholders and persons in charge-a system that facilitated arbitrary decisions (Akermann et al. 2012; Seglias 2013). Although the legal framework of the SCC represented the rule of law, the street-level practice implied violations of the principle of legal equality (ibid.).

The description of legal and institutional frameworks and placement practices shows that children were removed from their families for two main reasons: the alleviation and management of poverty (Seglias 2013; Furrer et al. 2014) and the imposing of social norms and discipline (Bütow et al. 2014; Guggisberg 2014; Thieme 2013). Placements and coercive welfare measures did not imply that persons concerned by state intervention in their civil rights had the opportunity to participate or be heard in legal decisions. This holds true for children in particular, who, for the greater part of the 20th century, were seen as immature, whose status was completely different from the present and who were stigmatized for being raised by "degenerate" or otherwise incapable families (Mazza Muschietti 2016). In this context, children's participation in the decision-making process was not even considered an issue. It was uncommon to announce a placement to the children involved, to mention reasons or give further information about the location or duration of it (ibid.). Moreover, given the absence (or weakness) of the state's supervisory function, a common consequence of coercive measures taken to "protect" children was that the placed children were left completely at the mercy of their carers (Leuenberger et al. 2011). The analysis shows that the personal and procedural rights of the persons concerned were practically non-existent for a long time and, although several legal and medical professionals were critical of this lack of protection, there was no public awareness of this systematic violation of their integrity, autonomy and participation.

\subsection{The Road to Change: Legal Developments and Changing Placement Practices after the Mid-20th Century}

Already at the end of the 19th century, and throughout the 20th century, there was criticism regarding some of the methods and approaches practiced in child and youth welfare, residential facilities and the placing of children as farmhands in families ("indentured child laborers") (Seglias 2013). Although there were selective efforts to improve placement settings and to introduce quality standards, a broad discussion of the practices of placements and coercive welfare measures carried out by the state did not arise (ibid.).

The shift in social values in the 1960s and 1970s contributed to a range of legal changes which had an impact on the legal foundation of child protection measures such as removals and placements (Seglias 2013). Reforms of the SCC in the 1970s, e.g., in family law, were concerned with the legal status of children. Legitimate and illegitimate children were given equal status and the best interest of the child was introduced as an important reference point in decisions that concerned him or her (ibid.). The ratification of the European Convention on Human Rights (ECHR) was an important milestone which led to a major reform of the law in 1981. The conditions for the deprivation of liberty defined in the ECHR (Art. 5) were henceforth imperative and Swiss law had to be adapted accordingly (Rietmann 2012; Independent Expert Commission (IEC) on Administrative 2019). These developments led to plans for a more thorough reform of the SCC with regard to the articles on child and adult protection. The reform process started in 1993 but the new law, introducing the new multi-professional Child and Adult Protection Authorities (CAPAs), did not enter into force before 2013 (Müller et al. 2020). The ratification of the UN Convention on the Rights of the Child in 1997 intensified the discourse on children's rights and the question of how to include children's perspectives in legal proceedings (ibid.). A reform of the divorce law in the year 2000 substantiated this question by giving the child the 
opportunity to be heard in family law, including child protection proceedings, which defined the child as a subject of the law (Cottier 2008).

Concerning the experiences of children placed in care, a range of biographical reports and studies in the 1970s and 1980s shed light on the living circumstances and perspectives of these children (summarized in Nett and Trevor 2012; Müller et al. 2020). After 2005, a number of studies analyzed Switzerland's detention practices during the 20th century (e.g., Leuenberger and Seglias 2008; Freisler-Mühlemann 2011; Ries and Beck 2013). However, despite these developments, which changed the way in which placements in the past were accounted for, research and activities to commemorate the experiences of formerly placed children organized by user/survivor organizations remained poorly funded up to around 2010, when the efforts made to obtain official recognition from the Swiss government were successful. An official apology and commemoration for all surviving victims of coercive welfare measures followed, and reparation payments were made in 2013 (Müller et al. 2020; Independent Expert Commission (IEC) on Administrative 2019). In the context of the political process, several research programs were initiated and funded (ibid.; NRP 76) which, together with the findings of earlier research, drew a more accurate picture of the Swiss welfare system and its practices in the 20th century. It became clear that these practices and experiences of abuse led to considerable health and psychological problems and prolonged socio-economic disadvantages for the children, youth and adults who were subjected to coercive welfare measures of several kinds (Independent Expert Commission (IEC) on Administrative 2019; Freisler-Mühlemann 2011; Akermann et al. 2012; Kuhlman et al. 2013; summarized in Schoch and Müller 2020). A further crucial finding of these studies was that the placed children experienced the disregard for their integrity and the denial of an opportunity to participate and be heard in decision-making as similarly traumatic to the original abuse and neglect which they had suffered in foster families and residential care facilities (Wohlwend and Honegger 2004; Freisler-Mühlemann 2011; Akermann et al. 2012; Leuenberger and Seglias 2008, 2015; Leuenberger et al. 2011).

\subsection{Reorganization and Professionalization of Child Protection: The Turning Point in 2013}

Due to the latest reform of child and adult protection, which was initiated in 1993 and implemented in 2013, the former layperson-based Guardianship Authority was replaced by the Child and Adult Protection Authorities (CAPAs). Child Protection Authorities became multi-professional decision-making bodies responsible for statutory child protection decisions.

The main results of the 2013 reform were the professionalization of decision-making in the Swiss child protection system and the reduction of the number of authorities from 1414 to 148. The legislator pursued the idea of a collegial body whose members apply expert knowledge from different fields and disciplines (such as law, social work, psychology, accounting and medicine) to meet the substantially diverse characteristics and requirements of complex cases (Cottier and Steck 2012; Schnurr 2017, pp. 125-27). Consequently, the law stipulates that the decisions of a CAPA must in principle be made by a quorum of three members. According to a recent evaluation survey, $93 \%$ of the CAPAs have multi-professional decision-making bodies, with law and social work being the most frequent combination (Rieder et al. 2016, p. 40). The CAPAs-unlike in other countries-are responsible for child as well as adult protection. It is at the discretion of the cantonal law makers whether CAPAs are administrative authorities or judicial authorities (courts). In addition, they can be cantonal, municipal or intercommunal/regional authorities. The population served by a CAPA varies from 2700 to 485,000 inhabitants, with the majority of CAPAs serving a population of more than 50,000 (KOKES 2017; Rieder et al. 2016, p. 9). Hence, there is diversity in the child protection regimes across the cantons.

As a general rule, the CAPA is obliged to hear a person affected by a decision "in person" (Art. 447 SCC) - an expression of the fundamental "right to be heard", as laid out in the Swiss Federal Constitution (Art. 29, 30 FC). Moreover, with respect to child protection proceedings, the SCC stipulates that "the child is heard in person in an appropriate manner by the child protection authority or by a third party appointed for this purpose, unless this is inadvisable due to the child's age or other good 
cause" (Art. 314a SCC). The explicit obligation to hear the child, introduced in 2000 in the context of the divorce law reform and strengthened by the reform of 2013, reflects the implementation of Art. 12 UN-CRC in the federal law on child protection. The Federal Supreme Court stipulates the right of a child to a hearing from six years old onward and indicates a (flexible) threshold of around 12 years for the acquisition of the capacity for judgement in family law matters, meaning that the child's view has more weight from this age on (Cottier 2017).

Besides the CAPA, which represents the statutory arm of the Swiss child protection system, there are social agencies (social services or children's services in a number of cantons) which are often referred to as "voluntary" child protection (Rosch and Hauri 2016). They bear responsibility for (1) facilitating access to non-statutory services for children and families and (2) decision-making on the non-statutory removal of children to alternative care. In addition, these agencies are often commissioned by the CAPAs to carry out assessments of the well-being of a child.

There is still considerable heterogeneity in the organization and form of the CAPAs, due to the federalist structure and the principle of subsidiarity, which regulate the competencies between the confederation, cantons and municipalities (Fassbind 2013, p. 15). As a consequence of the reform of 2013, a completely new administrative structure had to be established and new procedures and different forms of cooperation with relevant stakeholders needed to be developed (Fassbind 2013). Even though formal rights such as hearing the child's wishes, interests and views have been strengthened in child protection proceedings, there is still little knowledge available on the ways in which they are put into practice (Hitz Quenon et al. 2014; Hitz Quenon and Matthey 2017).

The reform of 2013 also triggered considerable criticism by the media, who worried that the new system would bring bureaucratization and overly intrusive interventions in families. The media also scandalized some problematic child protection cases and fueled the discussion on deficiencies in Swiss child protection (e.g., the case of Flaach: Direktion der Justiz und des Inneren 2016). A national report by the Federal Council attested to the CAPAs an appropriate standard of work and showed that the numbers of statutory measures in child and adult protection had not risen since the reform (Bundesrat 2017, p. 29). Nevertheless, the report recommended the development of appropriate standards-for instance, concerning the assessment of a child's needs and of the risks to his or her well-being.

\section{A Look Inside the CAPA: Interactions and Communication between Children, Parents and CAPA Members}

As stated earlier, little empirical knowledge is available on the current everyday practices of the Swiss Child and Adult Protection Authorities (CAPAs) or how individuals experience encounters with them. Our research project "Intapart: Integrity, Autonomy and Participation: How do children and parents experience child protection?" aims at closing this research gap. The following section gives insight into the findings of an in-depth investigation of children's and parents' interactions and communication with Swiss CAPAs, obtained through the analysis of participant observations of hearings. We first start with a description of our data and analysis methodology. We then focus on two fundamentally relevant themes discovered in the data: information exchange and interactions of recognition between CAPA members and individuals concerned. These two thematic complexes are central, since both information as well as interactions of recognition are seen as prerequisites for full participation as they extend and amplify opportunities to influence the outcome of the proceedings (agency). Further steps in our project will include qualitative interviews, questionnaires and focus groups.

\subsection{Methodological Approach}

We used participant observation as a method for qualitative data collection. Our main epistemological interest for the participant observations was to identify typical interactions and communications between CAPA members and parents and children. In line with Garfinkel's understanding of ethnomethodology, the aim was to grasp the production of "social reality of everyday 
activities". The stance of our observing researchers can be described as "passive participation", naively documenting the unknown (Spradley 1980; Pollner and Emerson 2001, pp. 121-25). The observed hearings were documented on the spot in the form of handwritten field notes (observation protocols). The field notes were taken in a structured manner, guided by an observation grid to augment verification and replication and to reduce researchers' bias (Angrosino and Perez 2000; Kawulich 2005). The common criteria for reliable and ethically sound field notes were followed with the observation grid (DeWalt and DeWalt 1998; Kawulich 2005; Merriam 1988; Olivier de Sardan 2008; Schensul et al. 1999). The mere and exact description of interactions in the order in which they occurred, including the exact time, were made. The participants present, a description of them, a spatial map indicating where individuals were seated, the physical surrounding and setting, informal exchanges and the researchers' personal feelings were noted too.

The participant observation was conducted by one or two experienced researchers over a period of eight months in 2019. Altogether, the sample consists of 24 hearings in 19 different cases in four CAPAs, covering a high degree of diversity in potential child endangerment situations, varying in intensity and severity. It is worth mentioning that we found that the four CAPAs varied in their degree of formality and structuring of the hearings and also differed in their organizational procedures.

Data were systematically coded using QDA software. For the analysis of the participant observations, we followed propositions of thematic analyses (Braun and Clarke 2006), with the aim of identifying themes in the data which are important in relation to the research question. Given the nexus of integrity, autonomy and participation as our focal point, we were interested in identifying themes relating to these three key concepts ("keyness" being a guiding principle to build codes and detect themes) (Braun and Clarke 2006, p. 82). We followed an "inductive development" of codes directly derived from the data; at the same time, our work was theoretically informed (ibid., p. 83). We focused on a "latent level" to identify relevant codes and themes, following a "constructionist perspective" to analyze the social production and structural conditions of the observed interactions (ibid., pp. 84-85).

Using a thematic analysis-inspired approach to analyze our data, two researchers worked as a team to elaborate thematic codes by coding the field notes of 24 hearings in 19 different cases in four CAPAs. Each code contained an "interesting aspect" and consisted of a thorough definition and coding rule, stemming from the data (Braun and Clarke 2006, p. 89). Based on the created codes, "themes" were identified which formed a "repeated pattern" and summarized interrelated sub-code-sets ("sub-themes") (ibid., pp. 89, 90). Working as a team during the coding development stage is a well-known strategy to ensure the reliability of the coding system (Armstrong et al. 1997). Within recurrent feedback loops with other researchers from the project team, the coding system was validated, refined and eventually regrouped into main themes. In fact, minor adjustments within the coding system were made throughout the whole coding process, to ensure that we grasped all important aspects contained in the data. Hence, we carried out the coding in an "ongoing organic" and "recursive process" (Braun and Clarke 2006, pp. 86, 91). This first analysis stage resulted in a coding system with ten main "themes" consisting of the following sub-code-sets: power dynamics, signs of recognition, expression of emotions, cooperation behaviors, negotiations around the problem definition, life domains, characteristics of the proceedings, definition of roles and perception of child protection.

\subsection{Results: "Information Exchange" and "Signs of Recognition" during the Hearings of Parents and Children}

As previously stated, the CAPA is the decision-making body for statutory child protection measures. The CAPA members make decisions on the basis of the assessment report (which is often produced by an external social service agency) and of the hearing with the concerned persons. Overall, our observations strongly support conceptualizations of decision-making in child protection, which emphasizes the procedural nature of such decisions (Bastian 2019; Forkby and Höjer 2011; Helm and Roesch-Marsh 2016; Pomey 2017). 
Based on the analysis of participant observations of hearings, we highlight two crucial themes which are highly relevant in order to understand interactions in terms of their potential to facilitate participation: information exchange and signs of recognition. Information exchange encompasses all exchanges between parents and children and CAPA members related to the child protection proceedings. Signs of recognition are organized into three groups-those related to legal rights, those related to love and those related to solidarity. We show how these were displayed by the authorities and responded to by the persons concerned and discuss their overall impact on participation.

Regarding information exchange, findings show that key information was systematically given orally by the CAPA to parents and children, mostly at the beginning of hearings but also frequently in interactions during the conversation. Information on the following issues was identified: the CAPA's tasks and organization; potential child protection measures; stages of the decision-making process; child protection procedure in general; legal rights and duties. This information exchange could be observed in all cases.

In only one observed case was printed information in the form of an information brochure handed out to parents at the hearing ${ }^{3}$. Information on the aspects mentioned was not only given to parents and children by the CAPA members but sometimes the individuals concerned also actively asked for it. A broad range of ways in which parents and children acted out their agency was observed, ranging from parents requesting an additional hearing in order to influence the intended decision to parents who remained more passive and did not take any anticipatory actions. In one case with two young parents-to-be, this exploration of their scope of action was very marked, since they actively and variously asked for the concrete consequences if they would not comply or would only partly comply with the CAPA. The CAPA members used this situation to repeatedly underline that, if at all possible, they would clearly aim for consensual agreements with the parents, but they also mentioned that they had the authority to make non-consensual decisions. We also observed wide variation in parents' and children's understanding of the child protection proceedings. Given the complexity of the child protection system and time constraints, we could document that misunderstandings happen at various stages of the hearing. While some misunderstandings were acknowledged by the CAPA members and resolved, others remained unnoticed. A commonly observed confusion was regarding the question of whether decisions had already been made or if the negotiation of the decision was still ongoing. We observed that the CAPA members tried to clarify this point, either by bringing it up by themselves or in reaction to parents explicitly expressing confusion over the stages of the decision-making process.

The analysis of information exchange leads us to the issue of the explicit recognition of legal rights. It is important to recall that the Child and Adult Protection Authority is structurally positioned within the family law system and is entitled to make statutory child protection decisions. The persons present at the hearings have thus been guaranteed the formal legal "right to be heard" by the CAPA. We repeatedly observed CAPA members referring to or explaining the legal framework to parents and children-for example, by informing them of their right to appeal against the decision or that the decision can only be taken by a quorum of three CAPA members, not merely by one. In Honneth's understanding (Honneth 1995), this can be read as a sign of recognition in the sphere of "rights", which encompasses the equality of people in terms of rights and fosters self-respect. We did not observe open exclusion of individuals from their rights, but we noticed some practices which could potentially lead to more subtle forms of denial. A quite commonly observed example of this could be seen when the CAPA requested parents to release professionals from their obligation to maintain confidentiality so that they could contact them regarding the child protection proceedings. In formal legal terms, it is correct to ask the parents to give their consent to release professionals from their obligation to maintain confidentiality. Interestingly, consent is usually reached quite incidentally, which, in one case

3 In this analysis, we did not include written communication such as the CAPA's invitation letter to the parents, which probably already contains information on the child protection proceedings. 
(second hearing), led to open criticism by a mother who felt that she had lost control over her personal information and felt passed over. The CAPA member tried to restore the mother's lost confidence in the CAPA by giving her further information on her right to define the exact scope of application which the release of obligation to maintain confidentiality encompasses.

Displaying legal authority by the CAPA can translate into signs of a lack of recognition and put a strain on the relationship. For instance, we observed that parents and children could perceive CAPA members mentioning legal obligations (such as the legal duty of parents to cooperate in the child protection proceedings) or describing possible legal consequences (such as mandated child protection measures against the will of the parents) as a threat that undermined their participatory agency. Hence, the recognition of parents and children on a legal level seems to be a sensitive issue. We also identified situations in which parents and children actively requested information on the legal framework of child protection proceedings. For example, a 14-year-old girl asked if her parents were allowed to decide against her will that she could not move out of the family home.

Apart from information exchange and the recognition of rights, two other forms of recognition proved to be critical to understanding the dynamics of hearings: recognition in terms of "love" and recognition in terms of "solidarity" (Honneth 1995). As delineated in the theoretical reflections, we conceptualize recognition as an integral part of integrity.

In the context of child protection, love is close to empathy and is an expression of a respectful and trusting relationship between the authorities and the persons concerned. Empathy was shown at different levels during hearings. Different behaviors expressed by CAPA members were indicators of such recognition: thanking parents and children for their presence; looking out for their physical well-being by offering them a glass of water; acknowledging signs of distress when someone was overcome by emotions. Even if parents and children are invited to a hearing by the CAPA, the observed practice of thanking parents and children for their attendance (instead of just greeting them) is a way to acknowledge them as individuals and to somewhat reduce the distance between persons concerned and the authorities. These behaviors seemed to have a positive impact on the interactions, helping to release tension and improve open communication. In contrast, ignoring tears or statements about not feeling well, interrupting explanations or correcting language errors had a negative impact. For instance, some CAPA members reformulated statements for the minute-taker (e.g., translating common terms to adequate legal terms, translating spoken terms to more formal written terms). This practice was perceived as unsettling by some parents who were interrupted and lost the train of their thoughts. Recognition of love/empathy is directly linked to people's self-confidence, and self-confidence increased or decreased as a result.

The third group of signs of recognition is related to solidarity, which encompassed being respectful of other people's opinions, attitudes, skills and roles or status. Parents and children were very sensitive to their views being understood and respected by the CAPA members. Interestingly, it seemed that obtaining the CAPA's approval was not the crucial point but rather listening attentively and acknowledging their perspective. Very simple and clear sentences like "I understand" and "Yes, it is difficult" seemed to foster feelings of recognition and enhance self-esteem. For instance, acknowledgments of the challenges of being a parent were met with relief by distressed parents who could more easily disclose their problems as a result. Solidarity was also shown the other way around when parents recognized that they had a need for support or agreed with an offer of support made by the authorities. CAPA members seemed to feel encouraged to have a supportive attitude and enhance cooperation as opposed to exerting power strategies. Moreover, we noticed that the most participative way to negotiate potential measures with parents or children was enhanced by formulations such as "what kind of support would you need?" rather than already suggesting a concrete measure. Indeed, this allows for a common definition of needs and potential solutions. In this regard, such open formulations are a recognition of the opinions of the persons concerned.

The opposite of solidarity was likely to happen in hearings with signs of disapproval, when parents' opinions were dismissed, delegitimized or contradicted. CAPA members would sometimes feel the need to correct or rectify parents' statements with the aim of fact-checking, establishing the 
truth or on moral grounds. Interestingly, however, it is possible to acknowledge a different opinion without approving it, as this may be enough to create a feeling of recognition and self-esteem. In one case, parents were expressing their disapproval of homosexuality based on their religious values. Two CAPA members challenged their view on two dimensions: human rights and a different interpretation of religious beliefs. The debate was heated and heading nowhere. A third CAPA member eventually stepped in and stated their respect for the parents' different views on this matter and then suggested focusing on the child's well-being and school achievement for the time being. This statement of recognition was enough to move the discussion forward and then to allow the parents to accept a child protection measure.

\section{Discussion}

The analysis indicates that there is a lack of information on the side of parents and children even in cases where CAPA members seem to follow the relevant organizational standard procedures to provide such information: for children and parents, it is often not clear what exactly the CAPA does, which stage of the decision-making process they are at, which measures the CAPA can take and what they potentially entail. In addition, the emotional dimension may make children and parents less able to process crucial information and to reflect rationally on their options. Subsequently, a full understanding of the child protection proceedings might be lacking in many cases. The hearing consequently must be understood as a situation where parents receive and have to process new information. The hearing can therefore be seen as a constitutive moment for parents and children as they make sense of their situation and the child protection proceedings and form their opinion. This adds to the original objective of hearings: giving the opportunity to bring in the perspective of the individuals concerned, their opinions and wishes and to discuss and negotiate the action to be taken. Not only are parents expected to give an account of their point of view but at the same time they have to explore the limitations of the context and their possible range of action by asking questions.

The hearing has the function of the legal instruction of the persons concerned on their rights and duties, which clarifies legal boundaries and opportunities for possible actions. As in the example mentioned, we observed that clarification of legal rights was often made in reaction to a comment or a question by parents or children but not systematically, since it is considered impossible to inform them about all their rights. It further remains unclear how well parents and children are informed in respect to their legal rights and duties, as the responsibility to make sure all individuals are equally informed of their rights and guaranteed the same rights is left fully to the CAPA. This may reproduce (or create) inequalities in understanding the child protection proceedings between individuals who are able and dare to actively seek information and less proactive individuals.

These results illustrate why being informed and understanding is such a crucial point for participation in child protection proceedings: as long as parents and children do not fully understand and are not well informed about the proceedings, their rights and duties, potential measures and their consequences or the CAPA's tasks, it is hard for them to know their scope of action (autonomy within the proceedings) and hence to fully participate. In addition, it is problematic if parents and children do not know which stage of the decision-making process they are at, since they do not recognize when they are at a crucial point at which they can influence the decision. Consequently, their agency can be considered restricted.

Overall, we observed signs of recognition in all cases but also signs of a lack of recognition in hearings. This might reflect the seemingly contradictory mission of the CAPA of protecting children and intervening in the family sphere if the child's well-being is endangered. They can, or sometimes have to, use their legal authority to impose constraining measures if individuals do not comply to ensure the child's well-being. Hence, the CAPA members are challenged to ensure parents' and children's participation by allowing a relationship of recognition (integrity) and providing a high level of information.

As in any qualitative study based on participant observation, the generalization of our results has some limitations. We have observed sequences of the everyday practice of four CAPAs located in two different language regions in Switzerland, in rural and urban settings. Even if our research sites have 
contrasting differences in relevant dimensions, the generalizability of the results presented above is limited. The "Intapart" research project will move on to explore in depth what children and parents experienced as supporting or hampering their integrity, autonomy and participation in their contact with the CAPA with qualitative interviews and focus groups and, later on, with a quantitative survey using questionnaires.

\section{Conclusions}

From the adoption of the Swiss civil code in 1912 to the reform of 2013, the Swiss child protection system has gone through tremendous changes, from systematic disregard for the integrity, autonomy and participation of parents and children in the past, towards an orientation that puts the persons concerned more and more at its heart. We propose a legally and historically informed perspective on child protection that builds the foundation for critical reflection and an analysis of current welfare practices and policies. It thereby aims to raise the awareness of child protection professionals regarding the conditions and settings that encourage and support the full participation of children and parents. This perspective further underlines the need for empirical knowledge on people's perspectives as the basis for the development of effective and sustainable practices in child protection proceedings, which secure the integrity, autonomy and participation of children and parents.

As our empirical analysis of the current practices of hearings at the Child and Adult Protection Authorities (CAPAs) in Switzerland shows, many parents and children entering the hearing do not seem to be well-enough informed. Collecting, processing and using information to identify one's scope of action within the child protection proceedings seems to be a central issue during hearings. Hearings should therefore be understood as situations of information exchange at multiple levels: informing parents and children about the child protection proceedings, the CAPA's tasks and potential measures, rights and duties and clarifying the stage within the decision-making process. Being informed and understanding the situation and one's rights and duties is crucial, since it is a prerequisite to forming and express one's opinion (acting autonomously) and to participating within a given structure. If parents and children experience recognition in the form of empathic and respectful interactions with the CAPA (integrity), they seem more likely to be at ease and able to participate. This means that CAPA members find themselves in very demanding situations when they interact with parents and children: they need to be highly sensitive to signs of misunderstanding, lack of information or discomfort and should be able to establish a relationship of recognition, i.e., to guarantee their interlocutors' integrity. Furthermore, when parents and children experience recognition through the assistance that child protection provides them in (re-)establishing supporting relationships, they are likely to be empowered to take "reasonable" decisions to live a self-determined life without state intrusion (autonomy).

Fostering participation in child protection proceedings should further be characterized by a power-sensitive approach, facilitating dialogical work with the concerned children and parents. Indeed, the establishment of a dialogic form of conversation can be a helpful starting point to establish full participation and a foundation for a relationship of recognition (Husby et al. 2019). Dialog can be understood as the production of shared meaning, not merely the understanding of one another's standpoint within a conversation. Hence, dialogic conversation suggests questioning existing assumptions, understandings and prejudices and shifts the perspective towards change (Graham and Fitzgerald 2010; Biesel et al. 2017). This aligns well with Habermas' concept of deliberation (Habermas 1981) and the basic idea "that in order to make legitimate decisions, one has to engage the people affected by these decisions in deliberating on what ought to be done" (Willumsen and Skivenes 2005, p. 198). Also referring to Habermas, Duncan sees the communication between children and professionals in child protection as systematically distorted by the power asymmetry between adults and children-for instance, by adults' power to judge what children say. A less distorted situation of communication could be achieved if everyone had the "same opportunity to talk and listen" and the same "right to question and answer". This would also limit the risk of trying to persuade others but instead facilitate the convincing of others of a better argument (Duncan 2019, p. 147). 
With our study, we hope to contribute to the development of sustainable child protection proceedings that provide effective support for children and parents, guaranteeing their integrity by allowing for the interaction of mutual recognition and making sufficient information available to the persons concerned for full participation in the child protection system.

Author Contributions: Conceptualization, A.S., G.A., B.M., K.B. and S.S.; methodology, A.S., G.A., B.M., L.S., K.B., M.C., G.S. and S.S.; formal analysis, A.S., G.A., B.M., L.S. and G.S.; investigation, A.S., G.A., B.M., L.S. and G.S.; writing original draft preparation, A.S., G.A., B.M., L.S., K.B., M.C., G.S. and S.S.; writing-review and editing, A.S., G.A., B.M., L.S., K.B., M.C., G.S. and S.S.; project administration, M.C., K.B. and S.S.; funding acquisition, M.C., K.B. and S.S. All authors have read and agreed to the published version of the manuscript.

Funding: This research was funded by the Swiss National Science Foundation (SNSF) grant number 407640_177445.

Acknowledgments: We first would like to thank all participants and partners for their engagement to realize this research project. We are also thankful for the support and commitment of the interns Aude Saugy and Mathilde Etienne and would like to thank Margaret Oertig for proofreading.

Conflicts of Interest: The authors declare no conflict of interest.

\section{References}

Affolter, Kurt. 2013. Die Totalrevision des Vormundschaftsrechts [The complete revision of the guardianship law]. SozialAktuell 45: 10-14.

Akermann, Martina, Markus Furrer, and Sabine Jenzer. 2012. Bericht Kinderheime im Kanton Luzern im Zeitraum von 1930-1970 [Report Children's homes in the canton of Lucerne in the period 1930-1970]. Luzern: Gesundheits- und Sozialdepartement des Kantons Luzern.

Alanen, Leena. 1988. Rethinking childhood. Acta Sociologica 31: 53-67. [CrossRef]

Ambert, Anne-Marie. 1986. Sociology of Sociology: The Place of Children in North American Sociology. Sociological Studies of Child Development 1: 11-31.

Anderson, Joel H., and Axel Honneth. 2005. Autonomy, Vulnerability, Recognition, and Justice. In Autonomy and the Challenges to Liberalism: New Essays. Edited by John Christman and Joel H. Anderson. New York: Cambridge University Press, pp. 127-49. Available online: http://dspace.library.uu.nl/handle/1874/20309 (accessed on 6 January 2020).

Angrosino, Michael V., and Kimberly A. Mays de Perez. 2000. Rethinking observation: From method to context. In Handbook of Qualitative Research, 2nd ed. Edited by Norman K. Denzin and Yvonna S. Lincoln. Thousand Oaks: Sage Publications, pp. 673-702.

Armstrong, David, Ann Gosling, John Weinman, and Theresa Marteau. 1997. The Place of Inter-Rater Reliability in Qualitative Research: An Empirical Study. Sociology 31: 597-606. [CrossRef]

Bastian, Pascal. 2019. Sozialpädagogische Entscheidungen [Decison-Making in Social-Pedagogy]. Opladen and Toronto: Barbara Budrich.

Becker-Lenz, Roland, and Silke Müller-Hermann. 2013. Die Notwendigkeit von wissenschaftlichem Wissen und die Bedeutung eines professionellen Habitus für die Berufspraxis der Sozialen Arbeit [The need for scientific knowledge and the importance of a professional habitus for the professional practice of social work.]. In Professionalität in der Sozialen Arbeit [Professionalism in Social Work]. Edited by Roland Becker-Lenz, Stefan Busse, Gudrun Ehlert and Silke Müller-Hermann. Wiesbaden: VS Verlag für Sozialwissenschaften, pp. 203-29. [CrossRef]

Biesel, Kay, Lukas Fellmann, Brigitte Müller, Clarissa Schär, and Stefan Schnurr. 2017. Prozessmanual: Dialogisch-Systemische Kindeswohlabklärung [Process Manual: Dialogic-Systemic Assessment of the Well-Being of the Child]. Bern: Haupt Verlag.

Biesel, Kay. 2016. Chancen und Risiken von Kinderrechten im Kinderschutz [Opportunities and risks of children's rights in child protection]. In Kinderrechte als Fixstern Moderner Pädagogik? Grundlagen, Praxis, Perspektiven [Children's Rights as a Fixed Star of Modern Pedagogy? Basics, Practice, Perspectives]. Edited by Luise Hartwig, Gerald Mennen and Christian Schrapper. Weinheim Basel: Beltz Juventa, pp. 241-49.

Bouma, Helen, Mónica López López, Erik J. Knorth, and Hans Grietens. 2018. Meaningful participation for children in the Dutch child protection system: A critical analysis of relevant provisions in policy documents. Child Abuse E Neglect 79: 279-92. [CrossRef] 
Braun, Virginia, and Victoria Clarke. 2006. Using Thematic Analysis in Psychology. Qualitative Research in Psychology 3: 77-101. [CrossRef]

Bühler-Niederberger, Doris. 2010. Introduction: Childhood Sociology—Defining the State of the Art and Ensuring Reflection. Current Sociology 58: 155-64. [CrossRef]

Bundesrat. 2017. Erste Erfahrungen mit dem Neuen Kindes- und Erwachsenenschutzrecht: Bericht des Bundesrates in Erfïllung der Postulate 14.3776, 14.3891, 14.4113 und 15.3614 [Initial Experiences with the New Law in Child and Adult Protection: Report of the Federal Council Answering the Parliamentary Postulates 14.3776, 14.3891, 14.4113 und 15.3614]. Bern: Schweizerische Eidgenossenschaft.

Bütow, Birgit, Marion Pomey, Myriam Rutschmann, Clarissa Schär, and Tobias Studer, eds. 2014. Sozialpädagogik Zwischen Staat und Familie. Alte und Neue Politiken des Eingreifens [Social Pedagogy between State and Families. Old and New Policies of Intervention]. Wiesbaden: VS Verlag für Sozialwissenschaften.

Corsaro, William A. 1997. The Sociology of Childhood. Thousand Oaks: Pine Forge Press.

Cossar, Jeanette, Marian Brandon, and Peter Jordan. 2016. 'You've got to trust her and she's got to trust you': Children's views on participation in the child protection system. Child E Family Social Work 21: 103-12. [CrossRef]

Cottier, Michelle, and Daniel Steck. 2012. Das Verfahren vor der Kindes- und Erwachsenenschutzbehörde [Procedures before the Child and Adult Protection Authority]. Praxis des Familienrechts 13: 981-1000.

Cottier, Michelle. 2008. Verfahrensvertretung des Kindes im Familienrecht der Schweiz: aktuelle Rechtslage und Reformbedarf [Legal representation of the child in Swiss family law: Current legal situation and need for reform]. In Anwalt des Kindes. Ein Europäischer Vergleich zum Recht des Kindes auf Eigene Vertretung in Behördlichen und Gerichtlichen Verfahren [Advocate for the Child. A European Comparison on the Right of the Child to be Represented in Administrative and Judicial Proceedings]. Edited by Stefan Blum, Michelle Cottier and Daniela Migliazza. Bern: Stämpfli, pp. 125-52.

Cottier, Michelle. 2017. L'enfant sujet de droit: bilan mitigé de la jurisprudence récente du Tribunal fédéral suisse [The child as a subject of law: a mixed record of the recent jurisprudence of the Swiss Federal Court]. In Le Droit en Question [The Law in Question]. Edited by Audrey Leuba, Marie-Laure Papaux Van Delden and Bénédict Foëx. Geneva: Schulthess éd. Romandes, pp. 81-100. Available online: https: //archive-ouverte.unige.ch/unige:92956 (accessed on 6 January 2020).

De Singly, François. 2000. Penser autrement la jeunesse [Thinking differently about youth]. Lien Social et Politiques 43: 9-21.

DeWalt, Kathleen M., and Billie R. DeWalt. 1998. Participant observation. In Handbook of Methods in Cultural Anthropology. Edited by H. Russell Bernard. Walnut Creek: AltaMira Press, pp. 259-300.

Dillon, Jo, Daz Greenop, and Mel Hills. 2016. Participation in child protection: A small-scale qualitative study. Qualitative Social Work: Research and Practice 15: 70-85. [CrossRef]

Dillon, Jo. 2018. 'Revolutionizing' Participation in Child Protection Proceedings. Ph.D. dissertation, Liverpool John Moores University, Liverpool, UK, December. Available online: https://pdfs.semanticscholar.org/efb5/ 0af382519e9861072fb10cf3d9fdc8b76960.pdf (accessed on 9 March 2020).

Direktion der Justiz und des Inneren. 2016. Aufsichtsrechtliche Würdigung der Handlungsweise der KESB Winterthur-Andelfingen im Fall Flaach [Regulatory appraisal of the CAPA's conduct in the Flaach Case]. Zürich: Kanton Zürich, Direktion der Justiz und des Inneren als Aufsichtsbehörde im Kindes- und Erwachsenenschutz.

Duerr Berrick, Jill. 2018. The Impossible Imperative. Navigating the Competing Principles of Child Protection. Oxford: Oxford University Press.

Dumbrill, Gary C. 2006. Parental experience of child protection intervention: A qualitative study. Child Abuse $\mathcal{E}$ Neglect 30: 27-37. [CrossRef]

Duncan, Mandy. 2019. Participation in Child Protection. Theorizing Children's Perspectives. Basingstoke: Palgrave Macmillan.

Esser, Florian, Meike S. Baader, Tanja Betz, and Beatrice Hungerland. 2016. Reconceptualising Agency and Childhood: New Perspectives in Childhood Studies. London: Routledge.

Fassbind, Patrick. 2013. Kantonale und innerkantonale Buntheit-Die Organisation der Kindes- und Erwachsenenschutzbehörden in der Schweiz [Cantonal and inner-cantonal colorfulness-The organization of child and adult protection authorities in Switzerland]. SozialAktuell 45: 15-17. 
Forkby, Torbjörn, and Staffan Höjer. 2011. Navigations between regulations and gut instinct: the unveiling of collective memory in decision-making processes where teenagers are placed in residential care. Child $\mathcal{E}$ Family Social Work 16: 159-68. [CrossRef]

Freisler-Mühlemann, Daniela. 2011. Verdingkinder-Ein Leben auf der Suche nach Normalität [Indentured Child Laborers-A Life in Search of Normality]. Bern: HEP.

Furrer, Markus, Kevin Heiniger, Thomas Huonker, Sabine Jenzer, and Anne-Françoise Praz. 2014. Einleitung [Introduction]. In Fürsorge und Zwang: Fremdplatzierung von Kindern und Jugendlichen in der Schweiz 1850-1980 [Welfare and Coercion: Placing Children in Care in Switzerland 1850-1980]. Edited by Markus Furrer, Kevin Heiniger, Thomas Huonker, Sabine Jenzer and Anne-Françoise Praz. Basel: Schwabe, pp. 7-23.

Graham, Anne, and Robyn Fitzgerald. 2010. Progressing children's participation: Exploring the potential of a dialogical turn. Childhood 17: 343-59. [CrossRef]

Guggisberg, Ernst, and Marco Dal Molin. 2019. Zehntausende. Zahlen zur Administrativen Versorgung und zur Anstaltslandschaft ["Tens of Thousands". Figures on Administrative Detention and on the Institutional Care Landscape]. Chronos Verlag, Éditions Alphil, Edizioni Casagrande. Zürich, Neuchâtel and Bellinzona: Independent Expert Commission (IEC) on Administrative Detention, vol. 6.

Guggisberg, Ernst. 2014. 'Brauchbare Glieder der Volksgemeinschaft'. Rezeption vereinsgetragener Fremdplatzierung anhand der Solothurner Armenerziehungsvereine, 1880-1930 ['Useful members of society'. Reception of placements conducted by charity associations using the example of the 'associations for the education of the poor' in the canton of Solothurn, 1880-1930]. In Fürsorge und Zwang: Fremdplatzierung von Kindern und Jugendlichen in der Schweiz 1850-1980 [Welfare and Coercion: Placing Children in Care in Switzerland 1850-1980]. Edited by Markus Furrer, Kevin Heiniger, Thomas Huonker, Sabine Jenzer and Anne-Françoise Praz. Basel: Schwabe, pp. 181-92.

Habermas, Jürgen. 1981. Theorie des Kommunikativen Handelns. [Theory of Communicative Action]. Frankfurt: Suhrkamp. Häsler, Mirjam. 2008. In Fremden Händen: Die Lebensumstände von Kost- und Pflegekindern in Basel vom Mittelalter bis heute [In the Hands of Strangers: The Living Condition of Placed Children in Basel from the Medieval Times to the Present]. Basel: Schwabe.

Healy, Karen, and Yvonne Darlington. 2009. Service user participation in diverse child protection contexts: Principles for practice. Child \& Family Social Work 14: 420-30. [CrossRef]

Helm, Duncan, and Autumn Roesch-Marsh. 2016. The Ecology of Judgement: A Model for Understanding and Improving Social Work Judgements. The British Journal of Social Work 47: 1361-76. [CrossRef]

Hillmann, Karl-Heinz. 1994. Wörterbuch der Soziologie [Dictionary of Sociology], 4th ed. Stuttgart: Alfred Kröner Verlag.

Hitz Quenon, Nicole, and Fanny Matthey. 2017. Une Justice Adaptée aux Enfants. L'audition lors d'un Placement en Droit Civil et Lors du Renvoi d'un Parent en Droit des étrangers [Child-Friendly Justice. The Hearing in Case of a Placement under Civil Law and Due to the Expulsion of a Parent under Migration Law]. Bern: Schweizerisches Kompetenzzentrum für Menschenrechte.

Hitz Quenon, Nicole, Eric Paulus, and Laure Luchetta Myit. 2014. Le Droit de Protection de l'enfant. Les Premiers Effets de la Mise en Oeuvre dans les Cantons de Genève, Vaud et Zurich [Child Protection Law. First Effects in the Cantons Geneva, Vaud and Zurich]. Bern: Swiss Centre of Expertise in Human Rights (SCHR), Available online: http://www.skmr.ch/cms/upload/pdf/150409_Studie_Kindesschutzrecht.pdf (accessed on 9 March 2020).

Honneth, Axel. 1995. The Struggle for Recognition: The Moral Grammar of Social Conflicts. Cambridge: MIT Press.

Husby, Inger Sofie Dahlø, Riina Kiik, and Randi Juul. 2019. Children's encounters with professionals-Recognition and respect during collaboration. European Journal of Social Work 22: 987-98. [CrossRef]

Husby, Inger Sofie Dahlø, Tor Slettebø, and Randi Juul. 2018. Partnerships with children in child welfare: The importance of trust and pedagogical support. Child E Family Social Work 23: 443-50. [CrossRef]

Independent Expert Commission (IEC) on Administrative, Detention, ed. 2019. Organisierte Willkür. Administrative Versorgungen in der Schweiz 1930-1981 (V. 10) [Organized arbitrariness. Administrative detention in Switzerland 1930-1981]. Zürich, Neuenburg and Lumino: Chronos Verlag, Éditions Alphil, Edizioni Casagrande.

Join-Lambert Milova, Hélène. 2006. Autonomie et participation d'adolescents placés en foyer (France, Allemagne, Russie) [Autonomy and participation of adolescents in residential care (France, Germany, Russia)]. Sociétés et Jeunesses en Difficulté. Available online: http://sejed.revues.org/index188.html (accessed on 9 March 2020).

Kawulich, Barbara B. 2005. Participant Observation as a Data Collection Method. Forum: Qualitative Social Research 6. [CrossRef] 
KOKES Konferenz für Kindes- und Erwachsenenschutz. 2017. KESB: Organisation in den Kantonen [CAPA: Organization in the Cantons]. (Stand 01.01.2017). Available online: https:/www.kokes.ch/application/files/ 5214/9027/3916/KOKES_KESB_Organisation_Kantone_ZKE_1-2017.pdf (accessed on 9 March 2020).

Kuhlman, Kate Ryan, Andreas Maercker, Rahel Bachem, Keti Simmen, and Andrea Burri. 2013. Developmental and Contextual Factors in the Role of Severe Childhood Trauma in Geriatric Depression: The Sample Case of Former Indentured Child Laborers. Child Abuse \& Neglect 37: 969-78. [CrossRef]

Lansdown, Gerison. 2010. The realisation of children's participation rights: Critical reflections. In A Handbook of Children and Young People's Participation. Edited by Barry Percy-Smith and Nigel Thomas. London and New York: Routledge, pp. 11-23.

Leuenberger, Marco, and Loretta Seglias. 2008. Versorgt und Vergessen. Ehemalige Verdingkinder Erzählen [Placed and Forgotten. Former Indentured Child Laborers Tell Their Stories]. Zürich: Rotpunktverlag.

Leuenberger, Marco, and Loretta Seglias. 2015. Geprägt fürs Leben. Lebenswelten Fremdplatzierter Kinder in der Schweiz im 20. Jahrhundert [Marked for Life. The Lives and Experiences of Placed Children in Switzerland in the 20th Century]. Zürich: Chronos.

Leuenberger, Marco, Lea Mani, Simone Rudin, and Loretta Seglias. 2011. 'Die Behörde Beschliesst'—Zum Wohl des Kindes? Fremdplatzierte Kinder im Kanton Bern 1912-1987 ['The Authority Decides'_For the Well-Being of the Child? Children Placed in Care in the Canton of Berne 1912-1978]. Baden: hier + jetzt.

Mazza Muschietti, Eva. 2016. Lebensbewältigung nach Zwangsmassnahmen und Fremdplatzierungen. Eine Vergleichende Analyse Ausgewählter Autobiographien von Betroffenen im Lichte der Resilienzforschung [Coping with Life after Coercive Welfare Measures and Placements. A Comparative Analysis of Selected Autobiographies in the Perspective of Research on Resilience]. Lausanne: IDHEAP Institut de Hautes études en Administration Publique, Université de Lausanne. Merriam, Sharan B. 1988. Case Study Research in Education: A Qualitative Approach. San Francisco: Jossey-Bass Publishers. Müller, Brigitte, Kay Biesel, and Clarissa Schär. 2020. Errors and Mistakes in Child Protection in Switzerland: A Missed Opportunity of Reflection? In Errors and Mistakes in Child Protection. International Discourses, Approaches and Strategies. Edited by Kay Biesel, Judith Masson, Nigel Parton and Tarja Pösö. Bristol: Policy Press, pp. 153-72. [CrossRef]

Nett, Jachen, and Spratt Trevor, eds. 2012. An International Study Comparing Child Protection Systems from Five Countries (Australia, Finland, Germany, Sweden, United Kingdom) That Provides Scientifically Founded Recommendations for Improving Child Protection in Switzerland. Bern: Programme National Pour la Protection de l'Enfant.

Olivier de Sardan, Jean-Pierre. 2008. La Rigueur du Qualitatif: Les Contraintes Empiriques de l'interprétation Socio-Anthropologique [The Rigor of the Qualitative: The Empirical Constraints of Socio-Anthropological Interpretation]. Anthropologie Prospective 3. Louvain-la-Neuve: Academia-Bruylant.

Pollner, Melvin, and Robert M. Emerson. 2001. Ethnomethodology and Ethnography. In Handbook of Ethnography. Edited by Paul Atkinson, Amanda Coffey, Sara Delamont, John Lofland and Lyn Lofland. London: Sage Publications, pp. 118-35. [CrossRef]

Pomey, Marion. 2017. Vulnerabilität und Fremdunterbringung. Eine Studie zur Entscheidungspraxis bei Kindeswohlgefährdung [Vulnerability and Placement in Care. A Study on Decisional Practice in Cases of Children at Risk]. Weinheim and Basel: Beltz Juventa.

Qvortrup, Jens. 1987. Introduction to Sociology of Childhood. International Journal of Sociology 17: 3-37. [CrossRef]

Raithelhuber, Eberhard, and Wolfgang Schröer. 2018. Agency [Agency]. In Handbuch Soziale Arbeit [Handbook of Social Work]. Edited by Hans-Uwe Otto, Hans Thiersch, Rainer Treptow and Holger Ziegler. München: Ernst Reinhardt Verlag, pp. 49-58.

Ramsauer, Nadja. 2000. 'Verwahrlost': Kindswegnahmen und die Entstehung der Jugendfürsorge im Schweizerischen Sozialstaat 1900-1945 ['Neglected': Child Removals and the Development of Child and Youth Welfare in the Swiss Welfare State 1900-1945]. Zürich: Chronos.

Rieder, Stefan, Oliver Bieri, Christoph Schwenkel, Vera Hertig, and Helen Amberg. 2016. Evaluation Kindes- und Erwachsenenschutzrecht. Analyse der Organisatorischen Umsetzung und Kennzahlen zu Leistungen und Kosten [Evaluation of the Child and Adult Protection Law. Analysis of the Organisational Implementation and Key Figures on Services and Costs]. Luzern: Interface Politikstudien Forschung Beratung, Available online: https://www.bj. admin.ch/bj/de/home/publiservice/publikationen/externe/2016-04-05.html (accessed on 9 March 2020).

Ries, Markus, and Valentin Beck. 2013. Hinter Mauern. Fürsorge und Gewalt in Kirchlich Geführten Erziehungsanstalten im Kanton Luzern [Behind Walls. Welfare and Violence in Church-Run Reformatories in the Canton of Lucerne]. Zürich: Theologischer Verlag Zürich. 
Rietmann, Tanja. 2012. 'Liederlich' und 'Arbeitsscheu'. Die Administrative Anstaltsversorgung im Kanton Bern, 1884-1981 ['Slovenly' and 'Work-Shy'. Administrative Detention in the Canton of Bern, 1884-1981]. Zürich: Chronos.

Rosch, Daniel, and Andrea Hauri. 2016. Begriff und Arten des Kindesschutzes. [Child Protection-Terms and Types] In Handbuch Kindes- und Erwachsenenschutz. Recht und Methodik für Fachleute [Handbook on Child and Adult Protection. Law and Methodology for Professionals]. Edited by Daniel Rosch, Christiana Fountoulakis and Christoph Heck. Bern: Haupt, pp. 406-9.

Rössler, Beate. 2017. Autonomie: Ein Versuch über das Gelungene Leben [Autonomy-An Essay on the Life Well-Lived]. Berlin: Suhrkamp.

Schensul, Stephen L., Jean J. Schensul, and Margaret D. LeCompte. 1999. Essential Ethnographic Methods: Observations, Interviews, and Questionnaires. Walnut Creek: AltaMira Press.

Schnurr, Stefan. 2017. Child removal proceedings in Switzerland. In Child Welfare Removals by the State: A Cross-Country Analysis of Decision-Making Systems. Edited by Kenneth Burns, Tarja Pösö and Marit Skivenes. International Policy Exchange. Oxford and New York: Oxford University Press, pp. 117-45.

Schnyder, Bernhard, Martin Stettler, and Christoph Häfeli. 1995. Zur Revision des Schweizerischen Vormundschaftsrechts. Bericht der vom Bundesamt für Justiz im Hinblick auf die Revision des Vormundschaftsrechts Eingesetzten Expertengruppe vom Juli 1995 [Revision of the Swiss Guardianship Law: Report of July 1995 by the Expert Group Commissioned by the Federal Office of Justice with a View to Revising Guardianship Law]. Bern: Bundesamt für Justiz, July 19.

Schoch, Aline, and Brigitte Müller. 2020. Eingriffe in Familien früher und Heute: Historische Beispiele von Kindswegnahmen und Einblicke in ein Laufendes Forschungsprojekt zur Aktuellen Kinderschutzpraxis in der Schweiz [State Interventions in Families in the Past and Present: Historical Examples of Placements and Insights into an Ongoing Research Project on Current Child Protection Practices in Switzerland]. Working paper, Sommerhochschule Kindesschutz Bremen, Schriftenreihe Bremer Schriften zur Sozialen Arbeit, City University of Applied Sciences. Bremen: Staats- und Universitätsbibliothek.

Seglias, Loretta. 2013. Heimerziehung-Eine historische Perspektive [Residential care-A historical perspective]. In Hinter Mauern [Behind Walls]. Edited by Markus Ries and Valentin Beck. Zürich: Theologischer Verlag Zürich, pp. 19-80.

Spradley, James P. 1980. Participant Observation. New York: Holt, Rinehart and Winston.

Steinmann, Gerold. 2014. Anspruch auf rechtliches Gehör (Abs. 2) [The right to be heard]. In Die schweizerische Bundesverfassung. St. Galler Kommentar [The Swiss Federal Constitution. St. Gallen Comment], 2nd ed. Edited by Bernhard Ehrenzeller, Rainer J. Schweizer, Benjamin Schindler and Klaus A. Vallender. Zürich: DIKE, pp. 660-71.

Svevo-Cianci, Kimberly A., Maria Herczog, Lothar Krappmann, and Philip Cook. 2011. The new UN CRC General Comment 13: The right of the child to freedom from all forms of violence-Changing how the world conceptualizes child protection. Child Abuse \& Neglect 35: 979-89. [CrossRef]

Swiss National Science Foundation (SNSF). 2020. The NRP. Available online: http://www.nfp76.ch/en/the-nrp (accessed on 9 March 2020).

Thieme, Nina. 2013. Kategorisierung in der Kinder- und Jugendhilfe. Zur Theoretischen und Empirischen Erklärung Eines Schlüsselbegriffs Professionellen Handelns [Categorization in Child and Youth Welfare. A Theoretical and Empirical Explanation of a Key Term of Professional Action]. Weinheim: Juventa.

Tisdall, E. Kay M. 2016. Subjects with agency? Children's participation in family law proceedings. Journal of Social Welfare and Family Law 38: 362-79. [CrossRef]

Willumsen, Elisabeth, and Marit Skivenes. 2005. Collaboration between service users and professionals: Legitimate decisions in child protection-A Norwegian model. Child \& Family Social Work 10: 197-206. [CrossRef]

Wohlwend, Lotty, and Arthur Honegger. 2004. Gestohlene Seelen: Verdingkinder in der Schweiz [Stolen Souls: Indentured Child Laborers in Switzerland]. Frauenfeld: Huber.

Wolff, Reinhard, Uwe Flick, Timo Ackermann, Kay Biesel, Felix Brandhorst, Stefan Heinitz, Mareike Patschke, and Pierrine Robin. 2016. Children in Child Protection. On the Participation of Children and Adolescents in the Helping Process: An Exploratory Study. 2. Contributions to Quality Development in Child Protection. Köln: National Centre on Early Prevention in Childhood (NZFH) within the Federal Centre for Health Educa-tion (BZgA).

(C) 2020 by the authors. Licensee MDPI, Basel, Switzerland. This article is an open access article distributed under the terms and conditions of the Creative Commons Attribution (CC BY) license (http://creativecommons.org/licenses/by/4.0/). 